\title{
PSALM 4: AMBIGUITY AND RESOLUTION
}

\author{
John Goldingay
}

\begin{abstract}
Summary
Translations of Psalm 4 differ at a number of points and thus point towards different understandings of it. In isolation, the opening verses do indeed raise a number of textual questions, and contain a number of interpretative ambiguities, which leave the reader in some uncertainty; but the last part of the psalm clarifies matters and makes it possible from the end to make coherent sense of the whole. Understanding the psalm thus turns out to resemble understanding a sentence, which cannot be grasped until we have reached the end of it.
\end{abstract}

\section{Introduction}

Ancient and modern versions of this short psalm differ significantly at a number of points and together indicate that we lack a coherent understanding of it. I began this paper with the hunch that most of these interpretative disagreements could not be resolved. As a prayer, the psalm's openness would then leave it available to be used in a variety of ways (24, I calculated at one stage, or was it 48?), while as a text for meditation it would work by driving readers to decide what they mean by it, and what this tells them. ${ }^{1}$ In studying it, I came to the conclusion that it illustrates a different point. The uncertainties attaching to individual verses cannot be resolved in isolation, but they find resolution by the end when we are in a position to look at the parts in light of the whole. ${ }^{2}$

1 In his paper 'Deliberate Ambiguity in the Psalter', JBL 110 (1991): 213-27, Paul R. Raabe takes two of his examples from Ps. 4.

2 Where not otherwise noted, translations are my own. Verse references are to those in printed Hebrew Bibles, but I omit the heading because I am concerned with the text of the psalm itself. 


\section{Verse 2}

For verse 2, there are three understandings:

A When I call, answer me, my true God. ${ }^{3}$ In $\mathrm{my}^{4}$ constraint you gave me room; ${ }^{5}$ be gracious to me and listen to my plea.

B When I call, answer me, my true God. In my constraint give me room; be gracious to me and listen to my plea.

C When I called, my true God answered me. In my constraint you gave me room; be gracious to me and listen to my plea.

The first version follows the traditional understanding of MT. The opening of the psalm then comprises two lines in abb 'a order in which the first and last cola comprise the psalmist's plea, while the middle cola state the basis for it in the nature of the God whom the psalm invokes (my true God), and in the past acts of that God (in my constraint you gave me room). After the opening imperative, these middle two cola encourage the psalmist and put pressure on God, first by a reminder of God's nature and then by giving specificity to the way this God has been 'true' in the past. It is on the basis of God's character and relations with the psalmist, and of God's past actions, that the psalm then returns to plea for the last colon, with two key urgings from such pleas.

The second version parallels NIV, which understands the perfect verb in verse 2, הרחבת, as a precative, thereby making the whole verse a plea. Waltke-O'Connor note that this proposed instance of precative perfect is preceded by an imperative and followed by two more, so that it well satisfies Buttenwieser's criterion that context should make it possible to recognise the precative perfect. ${ }^{6}$

3 'God of my צדק'. With NIV, I take this as an instance of a second noun in the genitive functioning as an adjective, the personal pronoun applying to the whole phrase. YHWH is God of צ's in the sense of being committed to doing the right thing by people, especially when they are in need.

4 Understanding the pronominal suffix from the context, specifically from the second colon, 'my plea'.

5 Noun and verb are antonyms. While צ commonly means 'distress' more generally, here the collocation with רחב ('be broad') suggests an awareness of the more specific root meaning of צר.

6 See Moses Buttenwieser, The Psalms (reprinted New York: Ktav, 1969): 18-25; Bruce K. Waltke and M. O'Connor, An Introduction to Biblical Hebrew Syntax (corrected printing; Winona Lake, IN: Eisenbrauns, 1991): 30.5.4. 
The third version follows LXX, which moves in the opposite direction by reading the opening colon as a statement rather than a prayer. The difference presupposes only a difference in the pointing

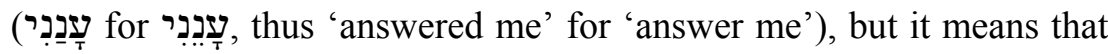
plea is confined to the last colon. The opening of the psalm thus puts the emphasis on the way God has answered prayer in the past, which is the basis for prayer in the present.

In that it follows MT's text and traditional grammar, the first version has tradition in its favour, although it is a little jerky. The second has the disadvantage of novelty but otherwise provides a straightforward understanding of the verse. The third keeps MT's consonants but comprises an alternative ancient tradition that also generates a coherent reading of the verse. In themselves, all are plausible understandings.

\section{Verses 3-4}

In verses 3-4, the subsequent questions and exhortations can be understood in two ways, as then can verses 3-6 as a whole. The suppliant addresses fellow-members of the community. It is perhaps too prosaic to ask after a material context in which the suppliant was both in God's presence and in the presence of these addressees, for example, in the temple. It is enough to imagine them present to the imagination.

3 You people, ${ }^{7}$ how long is my honour for shaming? How long will you dedicate yourselves to emptiness, have recourse to falsehood? (Selah)

4 Acknowledge that YHWH has set apart the committed person for himself. YHWH himself listens when I call to him.

'Honour' (כבוד) and 'shame' (כלמה) in verse 3 are another correlative pair, like 'constraint' and 'give room'. But whose honour and shame are referred to? Interpreted in light of the preceding psalm, the specific problem Psalm 4 addresses is that some people are treating the suppliant in the manner of Job's friends, who inferred from his

7 Lit. 'sons of an individual' (איש בני). Ovאיש). Over against the much more common 'sons of humanity' (אדם בני) this may imply important people (cf. Ps. 49:3; 62:10), but used on its own that may not be so (cf. Lam. 3:33). 
constraint or distress (e.g. Job 7:11) that he had lived in such a way as to deserve whatever had happened to him. Elihu specifically notes that YHWH is not doing what verse 2 has just described; delivering Job from constraint to a roomy place (Job 36:16). Job, too, thus exchanged honour (Job 19:9; 29:20) for humiliation (Job 16:10; 19:5). The second line then explains how the suppliant's 'friends' have turned honour to shame.

But wherein lie the 'emptiness' and 'falsehood' of their action? These words could denote moral emptiness, and refer to the lies people utter about the psalmist in the manner of Job's friends (cf. Ps. 5:7). Alternatively, emptiness could suggest futility, so that the people they are deceiving are themselves (as in Ps. 2:1). There are thus two ways to read verse $3 a$ when verse 3 is read in isolation.

But verse 4 will go on to urge the 'friends' to acknowledge the חסיד מס ('committed person') with whom YHWH identifies; the suppliant of course claims to be such a person. Their behaviour shows that they do not belong to this company, and they need to face the facts about their position. The rare verb 'set apart' (פלה) otherwise occurs only in connection with YHWH's treatment of the Israelites in Egypt (Exod. 8:18; 9:4; 11:7; cf. 33:16). ${ }^{8}$ The 'friends' are not behaving like proper Israelites, and they risk YHWH treating them like Egyptians rather than like Israelites. Verse $4 \mathrm{~b}$ draws out the implications of verse $4 \mathrm{a}$. The psalmist's position as a committed person whom YHWH has set apart means ' $Y H W H$ listens [the noun comes before the verb] when I call to him' - even though these other people do not. This statement of faith is the one whose truth the psalmist was asserting or claiming in verse 2: a bold statement, not least because it goes against the evidence (cf. v. 7).

Verse 4 as a whole thus clarifies that ambiguity in verse 3 . The 'emptiness' of their words is more likely their futility. By shaming the suppliant, they are behaving like the rebels in Psalm 2, not like servants of God; but this will get them nowhere as it gets those rebels nowhere. It is indeed themselves that they are deceiving (cf. Ps. 62:10; Isa. 28:15, 17).

So verses 3-6 could speak on behalf of someone whose personal honour is being questioned, the addressees being the suppliant's

8 Tg has 'separate' for פלה but LXX and Jerome take the verb as a byform of פלא, which the Cairo MS indeed has (cf. Ps. 17:8; 139:14) (cf. Peter C. Craigie, Psalms 150 [Waco, TX: Word, 1983]: 78). I would designate this an edifying misreading. 
personal assailants. The verses function somewhat like a lament (so NRSV implies), though the lament is diverted into preaching such as might enable people to articulate their sorrows if they want to avoid actually complaining at God.

But NIV points to a different meaning for verses 3-4 as a whole. YHWH is Israel's כבוד or glory (Ps. 106:20; Jer. 2:11) and is thus the psalmist's glory (BDB 459); and these people have changed this glorious one for something shameful. The sense in which the object of their dedication is empty is then defined by the words that follow: 'they have recourse to falsehood'. The expression recalls the use of 'falsehood' (כזב) to refer to other gods (Ps. 40:4; Amos 2:4), and the use of the verb 'have recourse to' (בקש) in connection with prayer to other gods (e.g. Ps. 27:4, 8; 105:4). The people the suppliant addresses are people who have recourse to other deities. NIV makes this explicit in its alternative translation of the first line in verse 3 and its main translation of the second line:

3 How long, O men, will you dishonour my Glorious One? How long will you love delusions and seek false gods?

The addressees are not merely personal assailants or people who attack the suppliant in YHWH's name, but people who are unfaithful to YHWH. It is against their delusions about YHWH and other gods that the psalm puts the real facts about YHWH's listening, from which they are hiding. In light of verse 3, the point about YHWH's listening is not that YHWH listens when no one else does, but that YHWH is the only God who really listens.

In isolation, either of these understandings of verses 3-4 seems plausible.

\section{Verses 5-6}

In verses 5-6 the psalmist continues urging proper attitudes on the mockers. I suggest the following translation:

5 Tremble, do not sin; say it ${ }^{9}$ within yourselves on your beds; be silent. ${ }^{10}$ (Selah)

9 There is no 'it': cf. Exod. 19:25; Judg. 17:2.

10 Or 'weep'. See e.g. John S. Kselman, 'A Note on Psalm 4, 5', Biblica 68 (1987): 103-5. 
6 Offer true sacrifices; trust in YHWH.

LXX and Jerome begin 'be angry' (cf. Eph. 4:26), but רגז never means that directly; it refers to physical perturbation. The cause of the perturbation has to be inferred from the context, which here suggests awe. 'Be angry but do not sin' is another suggestive, edifying reading, but even the immediate context indicates that it is not the inherent meaning of the line. The psalm rather urges trembling as an appropriate response of awed submission to YHWH (cf. Ps. 99:1) - in other words, as preferable to sinning against $\mathrm{YHWH}$.

For the third verb, modern translations have 'ponder in your hearts' or 'search your hearts', but this reads too much into the ordinary expression 'say in your hearts'. That is a common enough phrase, though with two contrasting possible significances. It can imply thinking things that we do not say aloud, and thus suggest falsehood or deceptiveness; or it can imply saying things inside and not merely outwardly, so that we say them and really mean them (cf. Ps. 10:13). ${ }^{11}$ The latter fits the context. The psalm is urging the addressees to acknowledge YHWH (v. 4) and really mean it. This understanding is confirmed by the succeeding reference to saying it on their beds, because the privacy of the bedroom is where people can think and say things they would not express publicly (Ps. 36:5; Eccl. 10:20; Mic. $2: 1){ }^{12}$ When they are on their beds, the psalm urges the addressees to make their acknowledgment of YHWH there rather than entertaining other secret thoughts. Silence is then a further sign of ceasing to speak wrongfully and of submitting oneself to YHWH (cf. Ps. 31:18-19; $37: 7 ; 62: 6)$. In verse 6 the psalm's urging closes with another brisk 2-2 line pairing with the one that opened the psalm; exhorting people to let their turning to YHWH expresses itself in the context of worship and of everyday life. 'True sacrifices' will be liturgically proper ones, but in light of the description of YHWH as 'true God' will also be ones where worship and life cohere. ${ }^{13}$

11 Michael Barré ('Hearts, Beds, and Repentance in Psalm 4, 5 and Hosea 7, 14', Biblica 76 [1995]: 53-62; see 59-60) notes that this expression elsewhere always intro-

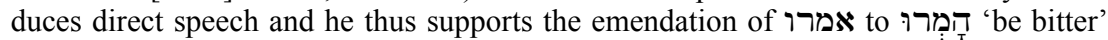
in the sense of 'weep bitterly'.

12 For the bed as a place of religious activity, see Isa. 57:7-8; Hos. 7:14; Ps. 149:5; Dan. 2, 4, 7; though a number of these passages are obscure.

13 Cf. Hans-Joachim Kraus, Psalmen, I. Teilband (Neukirchener: Neukirchen, 1978): 171; English translation: Psalms 1-59 (Minneapolis: Augsburg, 1988): 148. 
If verse 3 refers to attacks on the suppliant, then, verse 5 urges the abandoning of such negative intentions. If verse 3 refers to recourse to other gods, the trembling, avoidance of sin, inner acknowledgment, and silence that the psalm commends are expressions of submission to YHWH that replace recourse to other gods.

\section{Verse 7}

In verse 7 there is an ambiguity in MT's text:

A: There are many people saying, 'Who shows us good? Lift the light of your face on us, YHWH.'

B: There are many people saying, 'Who shows us good? The light of your face has fled from over us, YHWH.'

Before we come to that textual ambiguity, the verse raises three other questions. First, who are the 'many people'? Are they people with whom the suppliant would identify? Or are they the group addressed in verses 3-6, in which case this is the question underlying the clash between them and the psalmist? Or are they some other group, not so far mentioned? It is hard to decide between these possibilities in isolation.

Second, what kind of rhetorical question is the 'Who?' clause? BDB takes it as expressing a wish, but goes on to illustrate how a rhetorical מי ('who') clause is more commonly the equivalent of a statement. In this case that would be 'No one shows us good' (cf. Ps. 12:5; 76:8). Either way, the speakers do not have the good things they refer to. A further possibility is that they do have those good things and their words constitute another kind of rhetorical question. They know who they had been having recourse to (and it is not YHWH). Again, it is hard to decide between these possibilities in isolation.

Third, where do the words of the 'many people' come to an end? NIV and JPS close the quotation after the first colon and invite us to see the second colon as the suppliant's own words, while NRSV continues the quotation through to the end of verse 7 . The immediate context makes it easier to decide between these possibilities. Both cola refer to 'we' and it is natural with NRSV to read the whole verse as referring to the same 'we'; it is the transition to verse 8 that marks the transition from 'we' to 'I'. Hypothesising a transition to the suppliant's words within verse 7 works against the poetry. 
Verse $7 \mathrm{~b}$ concerns the implementing of Aaron's blessing (Num. 6:24-26): the word 'face' recurs, and 'light' comes from the verb ('shine'). It is here that MT's text raises a question. MT's verb reads נִסָד, which I take as a composite form combining the consonants of נָָָָ , נסָה ('flee'), and נשא נשא ('lift'). The form fromels of the imperative from (version A above) extends the reference to Aaron's blessing in making a plea that urges on YHWH the act that verse 7a points to, 'Lift the light of your face on us.' In contrast to the opening prayer (v. 2), this plea concerns not the suppliant's individual need but the need of a group of people who look to YHWH. The consonantal text implies that their words are not a plea at all but a statement or an expression of pain: 'The light of your face has fled from over us.' ${ }^{14}$ Either reading is plausible in itself.

\section{Verses 8-9}

Verses 8-9 raise another significant question of interpretation, but they also provide a key pointer to the resolving of most of the major uncertainties we have noted.

8 You put joy in my heart at the time when their grain and wine increase.

Or You put joy in my heart more than when their grain and wine increase.

9 In peace/well-being I shall lie down and sleep at once, ${ }^{15}$ Because you alone are YHWH; you make me live in security. ${ }^{16}$

In verse 8, the first version follows the understanding of מעת in LXX and Jerome ('at the time'), taking the preposition as the מעg than precede a temporal expression but lose its force (BDB 581). NRSV and NIV take the preposition as comparative מן, so that the expression

14 J. H. Eaton, 'Psalm 4:6-7', Theology 67 (1964): 355-57, argues for this translation. LXX 'was marked' also constitutes a statement rather than a prayer (like its version of

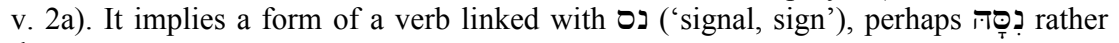
than

15 When it follows two verbs, יחדו ('at once') serves to hold them together and suggest simultaneity. I assume the usage here is similar, though the word precedes the verbs.

16 LXX takes the second line as one clause: 'You, YнwH, alone enable me to live in security;' but 'You alone [are] YHWH' looks like a confession of faith that then gives the basis for the second clause. More likely MT is thus right to take the line as two clauses. 
signifies 'more than [the time] when ...': inner joy more than compensates for outer lack. M. Mannati suggests rather 'from the time'. ${ }^{17}$ Once more, in isolation we cannot determine which possibility to choose.

The psalm closes with a statement of faith that YHWH's involvement will not stop at the gift of inner joy but will also convey שלום. Once again there are two ways to understand this expectation. Modern translations take שלום to denote peace or safety from foes (cf. Ps. $28: 3 ; 120: 7)$, and the reference in the last colon to living in security could fit with that understanding. If verses 3-4 implied attacks on the suppliant, that would also fit. Either way, the psalmist intends to lose no sleep over whether there is food to eat or foes to face. But שלום often refers to a fuller well-being of the whole person (e.g. Ps. 37:11; $38: 3$ [4]; 72:3), and 'living in security' is a frequent description of God's ideal intention for Israel (e.g. Lev. 25:18-21; 33:28; 1 Kgs 4:25 [5:5]; Ezek. 34:25-29) that includes the idea of crops growing well.

Strictly, 'You alone are YHWH' is a tautology, the effect being heightened if in light of the word order we translate 'You are YHWH, you alone.' But in such statements the implication is that being YHWH means being the only God who counts. It is correlative to YHWH's declaration, 'I am YHWH and there is no other' (Isa. 45:5, 6, 18). There is only one answer to the question 'Who will show us any good?'

The ambiguity about both verse 8 and verse 9 in isolation from each other is clarified when they are seen in light of each other. First, whichever way we read verse 9 , it indicates that the psalm is not just interested in inner joy, supporting the understanding of verse 8 in LXX and Jerome. Second, the fact that verse 7 took up the words of Aaron's blessing, which closes with the gift of שלום, suggests that in verse 9 שלום and security have the broader rather than the narrower meaning. That reinforces the likelihood that LXX and Jerome are right in verse 8. The suppliant does have joy even when lacking other good things, but does not prioritise such joy - which would be an odd attitude for an Old Testament writer to take - and expects YHWH also to give the other good things.

Clarifying the understanding of verses 8-9 makes it possible then to revisit the earlier ambiguities. First, the 'their' in verse 8 refers back to the 'many people' of verse 7 and resolves the question about their

17 'Sur le sens de min en Ps. iv 8', VT 20 (1970): 361-66. 
identity. They are not a group with whom the suppliant identifies. Further, the description of them as a group set over against the suppliant fits the description of the addressees of verses 3-6. The hypothesis that they are a totally different group is unnecessary and falls to Occam's razor ('entities are not to be multiplied').

Their rhetorical question about where 'good' comes from (v. 7) is given more precision in verse 8 by the reference to good things such as the fruitfulness of the harvest (e.g. Ps. 5:13; 34:11; 65:12). These people do have good things: grain and wine. This clarifies that their question did not signify either a wish or a negative statement. So what was the expected answer to it? It implied 'Not YHWH', and presumably more specifically 'Baal'. They then have no reason to go on to ask that the light of YHWH's face be lifted over them. Rather, they are declaring that YHWH had indeed turned away from them; but this no longer worries them, because they have found another god who responds to them.

In turn this clarifies the ambiguity about verses 3-6. These people have been having recourse to Baal. These are people who have proved that having recourse to Baal works, whereas recourse to YHWH does not work. It is YHWH they are attacking, not the suppliant. The suppliant, however, knows that eventually YHWH will grant these blessings and thus has an inner joy. The point is not that this compensates for hunger but that it responds to the certainty that YHWH will grant שלום in due course.

In turn, this understanding of verses 3-9 clarifies the question about verse 2 . Initially it draws attention to an oddity about verse 2 , in which all three versions close with a plea. So what is the psalm's plea? There is no plea in the following verses 3-6, which rhetorically confront people who have a bad attitude, though they no doubt imply a desire that God may change these people. We have concluded that there is no plea in verse 7, and even if there is one, it is uttered by people the psalm is quoting, not by the suppliant, and it may not be seriously meant. And there is no plea in verses 8-9; only a declaration of trust in YHWH. So the only plea in the psalm is the opening plea to listen to a plea, in verse 2 . There is no plea to which this plea refers.

The problem of identifying the psalmist's plea points us to the fact that formally the psalm is more a declaration of trust than a request for 
help. ${ }^{18}$ We might wonder whether the request to God to listen to the suppliant's תפלד ('prayer, plea', v. 2) uses this noun in the way English can use the word 'prayer', to refer to address to God that does not focus on asking for things. The verb 'pray', (התפלל), is used thus (see 1 Sam. 2:1; Jon. 2:2), but there are no other definite examples of the noun תפלה used in this way. More likely, then, the psalm is urging God to pay heed to a plea. And as there is no subsequent plea in the psalm, this suggests we should not eliminate the plea from verse $2 \mathrm{a}$, with LXX. ${ }^{19}$

Indeed, the oddity indicates that the broader as well as the narrower context of the psalm supports the precative understanding of הרחבת, ('give me room'), in verse 2 b. An isolated past reference there is, in any case, strange; the psalm gives no further indication of what this earlier giving of room might have been. ${ }^{20}$ If we take verse 2 as a whole to comprise a series of pleas, this makes sense of the closing appeal to 'be gracious and listen to my plea'. It is the preceding clauses in the verse that comprise the plea the psalm asks God to listen to.

\section{Conclusion}

By the end of the psalm, then, we know how to read it.

2 When I call, answer me, my true God. In my constraint give me room; be gracious to me and listen to my plea.

3 You people, how long is my glorious one for shaming, How long will you dedicate yourselves to emptiness, have recourse to falsehood? (Selah)

4 Acknowledge that YHWH has set apart the committed person for himself; YHWH himself listens when I call to him.

5 Tremble, do not sin; say it within yourselves on your beds; be silent. (Selah)

6 Offer true sacrifices; trust in YHWH.

18 So e.g. Arnold A. Anderson, Psalms, Vol. 1 (London: Oliphants, 1972): 76.

19 Cf. (e.g.) Erhard S. Gerstenberger, Psalms Part 1 (FOTL 14; Grand Rapids: Eerdmans, 1988): 57; against (e.g.) Artur Weiser, Die Psalmen: Erster Teil (6th edn; Göttingen: Vandenhoeck, 1963): 80; English translation from the 5th edn: The Psalms (Philadelphia: Westminster/London: SCM, 1962): 119.

20 Thus Kraus, Psalmen, I:166 (English translation 145), comments that this clause 'has a strange position, as if it were an interpolation'. 
7 There are many people saying, 'Who shows us good? The light of your face has fled from over us, YHWH.'

8 You put joy in my heart

at the time when their grain and wine increase.

9 In well-being I shall lie down and sleep at once, Because you alone are $\mathrm{YHWH}$; you make me live in security. 